\title{
Pengetahuan Ibu Tentang Perkembangan Motorik Kasar pada Balita usia 3-4 Tahun
}

\author{
${ }^{1}$ Darah Ifalahma*, ${ }^{2}$ Nur Hikmah \\ ${ }^{1}$ Fakultas Ilmu Kesehatan, Universitas Duta Bangsa Surakarta \\ ${ }^{2}$ Fakultas Ilmu Kesehatan, Universitas Duta Bangsa Surakarta \\ *darah_ifa@udb.ac.id
}

\begin{abstract}
Abstrak
Masa balita disebut golden periode karena mempunyai potensi yang sangat besar untuk mengoptimalkan segala aspek perkembangan. Perkembangan setiap anak akan melalui tahapan yang berlangsung secara berurutan, terus menerus dan dalam tempo tertentu. Dengan memahami tahapan perkembangan seorang anak, orang tua akan dapat menilai perkembangan anak sesuai dengan patokan umum yang berlaku. Apabila diamati anak yang mengalami keterlambatan perkembangan, orang tua bisa segera bertindak. Sebaliknya, orang tua juga bisa mempersiapkan anak dengan memberi stimulasi yang sesuai dengan kemampuan anak pada usia tertentu. Pengetahuan dan kesadaran orang tua sangat perlu untuk memantau dan memberi rangsangan pada perkembangan anak. Tujuan penelitian untuk mengetahui pengetahuan ibu tentang perkembangan motorik kasar pada balita usia 3-4 tahun.

Desain penelitian ini mengunakan metode penelitian deskriptif. Instrumen yang digunakan adalah kuesioner. Sampel penelitian ini adalah ibu yang mempunyai balita di Playgroup Cepaka 2 Semanggi Surakarta sejumlah 35 responden. Teknik pengambilan sampel secara Nonprobability Sampling dengan sampel jenuh. Analisis data menggunakan analisa univariat.

Hasil penelitian adalah tingkat pengetahuan ibu tentang perkembangan motorik kasar pada balita secara keseluruhan responden memiliki pengetahuan yang baik yaitu 2 orang $(5,7 \%)$, responden yang berpengetahuan cukup yaitu 19 orang $(54,3 \%)$ dan responden yang berpengetahuan kurang yaitu 14 orang $(40 \%)$.

Kesimpulan pengetahuan ibu tentang perkembangan motorik kasar pada balita mayoritas dalam kategori cukup. Saran untuk ibu diharapkan meningkatkan kesadaran pentingnya untuk menambah pengetahuan tentang perkembangan motorik kasar pada balita.
\end{abstract}

\section{Kata Kunci : pengetahuan, perkembangan motorik kasar, balita}

\begin{abstract}
The toddler period is called the golden period because it has enormous potential to optimize all aspects of development. The development of each child will go through stages that take place sequentially, continuously and within a certain tempo. By understanding the stages of a child's development, parents will be able to assess the child's development according to generally accepted standards. If a child is observed who has developmental delays, parents can act immediately. Conversely, parents can also prepare children by providing stimulation in accordance with the child's abilities at a certain age. Knowledge and awareness of parents is very necessary to monitor and stimulate children's development. The research objective was to determine the knowledge of mothers about gross motor development in children aged 3-4 years.

This research design uses descriptive research method. The instrument used was a questionnaire. The sample of this research is mothers who have children under five in Playgroup Cepaka 2 Semanggi Surakarta with a total of 35 respondents. The sampling technique is nonprobability sampling with saturated samples. Data analysis used univariate analysis.

The results of the study were the level of maternal knowledge about gross motor development in toddlers. Overall, the respondents had good knowledge, 2 people (5.7\%), 19 people (54.3\%) with sufficient knowledge, and 14 people with less knowledge (40.0\%).

The conclusion of the mother's knowledge about gross motor development in toddlers is in the moderate category. Suggestions for mothers are expected to increase awareness of the importance of increasing knowledge about gross motor development in toddlers.
\end{abstract}

Keywords: knowledge, gross motor development, toddlers 


\section{PENDAHULUAN}

Menurut Depkes Sulistiyawati (2014) masa pra sekolah disebut masa keemasan (Golden period), jendela kesempatan (window of opportunity), dan masa kritis (critical period). Dimasa pra sekolah terdapat berbagai tugas perkembangan yang harus dikuasai anak sebelum dia mencapai tahap perkembangan selanjutnya, adanya hambatan dalam mencapai tugas perkembangan tersebut akan menghambat perkembangan selanjutnya.

Menurut Adriani (2013) dalam perkembangan anak terdapat masa kritis, dimana diperlukan rangsangan atau stimulus yang berguna agar potensi berkembang, sehingga perlu mendapatkan perhatian. Periode penting dalam tumbuh kembang anak adalah masa balita, karena pada masa ini merupakan pertumbuhan dasar yang akan mempengaruhi dan menentukan perkembangan anak selanjutnya. Pada masa balita ini perkembangan kemampuan berbahasa, kreatifitas, kesadaran sosial, emosional, dan intelegensia berjalan sangat cepat dan merupakan landasan perkembangan berikutnya.

Perkembangan adalah bertambahnya kemampuan dan struktur / fungsi tubuh yang lebih kompleks dalam pola yang teratur, dapat diperkirakan, dan diramalkan sebagai hasil dari proses diferensiasi sel, jaringan tubuh, organ-organ, dan sistemnya yang terorganisasi. Dengan demikian, aspek perkembangan ini bersifat kualitatif, yaitu pertambahan kematangan fungsi dari masing-masing bagian tubuh.Hal ini diawali dengan berfungsinya jantung untuk memompa darah, kemampuan untuk bernafas, sampai kemampuan untuk tengkurap, duduk, berjalan, bicara, memungut benda-benda di sekelilingnya, serta kematangan emosi dan sosial anak. Tahap perkembangan awal akan menentukan tahap perkembangan selanjutnya (Nursalam, dkk, 2008).

Motorik kasar merupakan keterampilan menggerakkan bagian tubuh secara harmonis dan sangat berperan untuk mencapai keseimbangan yang menunjang motorik halus.Permasalahan yang sering terjadi pada anak TK adalah anak masih labil atau sulit menggerakkan bagian tubuh secara harmonis. Misalnya: berjalan, berlari, menangkap, melempar. Selain itu juga belum sempurnanya koordinasi dalam mengontrol motorik kasar, misalnya jika ditugaskan untuk berjalan tanpa menyentuh temannya (Adriani, 2013)

Menurut Safitri (2012) Perkembangan setiap anak akan melalui tahapan yang berlangsung secara berurutan, terus menerus dalam tempo perkembangan tertentu, dan bisa berlaku umum. Dengan memahami tahapan perkembangan seorang anak, orang tua akan dapat menilai perkembangan anak sesuai dengan patokan umum yang berlaku. Apabila diamati anak yang mengalami keterlambatan perkembangan, orang tua bisa segera bertindak. Sebaliknya, orang tua juga bisa mempersiapkan anak dengan memberi stimulasi yang sesuai dengan kemampuan anak pada usia tertentu.

Menurut Dewi (2013) stimulasi merupakan cikal bakal proses pembelajaran anak. Stimulasi ini terdiri atas pendidikan dan pelatihan.Stimulasi dini berasal dari rangsangan yang ada di lingkungan anak, seperti bermain, berdiskusi, dan lainlain.Selain itu, stimulasi ini juga bisa berasal dari orang tua.

Studi pendahuluan di Playgroup Cepaka 2 Semanggi Surakarta, dari 35 balita terdapat balita usia 3-4 tahun yang mengalami perkembangan tidak sesuai dengan umurnya seperti belum dapat berdiri dengan 1 kaki, melompat dengan 1 kaki serta berlari masih terjatuh.

Tujuan penelitian adalah mengetahui tingkat pengetahuan ibu tentang perkembangan motorik kasar pada balita umur 3-4 tahun di Playgroup Cepaka 2 Semanggi Surakarta.

\section{TINJAUAN PUSTAKA}

\section{Pengetahuan}

a. Pengertian

Pengetahuan adalah hasil 'tahu', dan ini terjadi setelah orang melakukan pengindraan terhadap suatu obyek tertentu. (Notoatmodjo, 2011).

b. Tingkat Pengetahuan Menurut Notoatmodjo (2011) pengetahuan yang dicakup dalam domain kognitif mempunyai enam tingkat, yaitu:
1) Tahu (Know)
2) Memahami (Comprehension)
3) Aplikasi (Aplication)
4) Analisis (Analysis)
5) Sintesis (Synthesis)
6) Evaluasi (Evaluation)

c. Cara Memperoleh Pengetahuan Menurut Notoatmodjo (2010) cara untuk memperoleh kebenaran pengetahuan dapat dikelompokkan menjadi 2 yaitu sebagai berikut:

1) Cara Tradisional atau Non Alamiah
a) Coba-coba Salah (Trial and Error)
b) Secara Kebetulan
c) Cara Kekuasaan atau Otoritas
d) Berdasarkan Pengalaman Sendiri
e) Cara Akal Sehat (Common Sense)
f) Kebenaran Melalui Wahyu
g) Kebenaran Secara Intutitif
h) Melalui Jalan Pikiran
i) Induksi
j) Deduksi

2) Cara Alamiah atau Modern 
Cara ini disebut dengan metode penelitian ilmiah atau metodologi penelitian (Research Metodology).

d. Faktor-faktor yang Mempengaruhi Pengetahuan Menurut Ariani (2014), pengetahuan baik yang dimiliki seseorang dipengaruhi oleh beberapa faktor diantaranya yaitu:

1) Faktor Internal
a) Umur
b) Jenis Kelamin
c) Pendidikan
d) Pekerjaan

2) Faktor Eksternal
a) Lingkungan
b) Sosial Budaya
c) Status Ekonomi
d) Informasi

2. Perkembangan Motorik

a. Pengertian

Perkembangan motorik kasar merupakan gerakan fisik yang membutuhkan keseimbangan dan koordinasi antar anggota tubuh, dengan menggunakan otototot besar, sebagian atau seluruh anggota tubuh (Soejiningsih, 2012).

b. Macam Perkembangan Motorik Kasar Menurut Mahendra (2006) macam perkembangan motorik kasar dibagi menjadi tiga katagori yaitu:

1) Keterampilan Lokomotor

2) Keterampilan Nonlokomotor

3) Keterampilan Manipulatif

c. Unsur Perkembangan Motorik Kasar

Menurut Barrow Harold M., dan Mc Gee, Rosemary dalam Khoiriyah (2013) unsur unsur perkembangan motorik kasar yaitu:

1) Kekuatan

2) Koordinasi

3) Kecepatan

4) Keseimbangan

5) Kelincahan

d. Faktor - Faktor Yang Mempengaruhi Perkembangan Motorik Kasar

Menurut Soetjiningsih (2012), faktorfaktor yang mempengaruhi kualitas tumbuh kembang anak antara lain:

1) Motivasi Belajar Anak

2) Pengetahuan Ibu

3) Lingkungan

4) Pendapatan

e. Masalah Perkembangan Motorik Kasar Perkembangan motorik kasar yang lambat dapat disebabkan oleh beberapa hal. Tidak semua anak usia dini mengalami perkembangan motorik kasar yang optimal sesuai dengan pertambahan usianya. Ada berbagai hal yang menjadikan masalah dalam perkembangannya antara lain:
1) Ketidakmampuan mengatur keseimbangan

2) Reaksi kurang cepat dan koordinasi kurang baik

\section{METODE}

Lokasi penelitian dilakukan di Playgroup Cepaka 2 Semanggi Surakarta. Jenis penelitian yang digunakan adalah penelitian deskriptif. Penelitian deskriptif adalah sekumpulan objek yang biasanya bertujuan untuk melihat gambaran fenomena (termasuk kesehatan) yang terjadi di dalam suatu populasi tertentu (Notoatmodjo, 2010).

Populasi yang digunakan dalam penelitian ini adalah seluruh ibu yang mempunyai anak di Playgroup Cepaka 2 Semanggi Surakarta. Pada penelitian ini sampel yang digunakan adalah seluruh ibu yang mempunyai anak di Playgroup Cepaka 2 Semanggi Surakarta yaitu 35 orang. Teknik sampling pada penelitian ini menggunakan teknik Nonprobability Sampling yaitu teknik pengambilan sampel yang tidak memberi peluang atau kesempatan sama bagi setiap unsur atau anggota populasi untuk dipilih menjadi sampel, oleh karena itu dalam penelitian ini peneliti menggunakan Sampling Jenuh yaitu teknik penentuan sampel bila semua anggota populasi digunakan sebagai sampel (Sugiyono, 2009).

Jenis pengumpulan data terbagi menjadi 2 yaitu (1) Data Primer, (2) Data Sekunder. Instrumen Penelitian adalah alat-alat yang digunakan untuk pengumpulan data.. Penelitian ini menggunakan kuesioner tertutup yaitu kuesioner yang hanya berisi dua jawaban atau alternatif, dan responden hanya memlih satu diantaranya (Notoatmodjo, 2010).

Analisis data yang digunakan dalam penelitian adalahan alisis univaria tyaitu menganalisa terhadap variabel dari hasil tiap penelitian untuk menghasilkan distribusi frekuensi dan prosentase dari variable Analisis univariatnya adalah tingkat pengetahuan. Rumus analisis univariate adalah

$$
\mathrm{P}=\mathrm{E}_{\mathrm{n}} \mathrm{x} 100 \%
$$

keterangan :

$$
\begin{array}{ll}
\mathrm{P} & \text { : Prosentase } \\
\mathrm{n} & \text { : Jumlah Pertanyaan } \\
\mathrm{f} & \text { : Jumlah jawaban benar }
\end{array}
$$

(Budiarto, 2011)

Hasil perhitungan prosentase tentang pengetahuan dimasukkan ke dalam standar kriteria objektif. Kriteria tersebut yaitu:

Baik : jawaban kuesioner benar 76\%-100\%

Cukup : jawaban kuesioner benar 56\%-75\%

Kurang : jawaban kuesioner benar $<56 \%$

Ariani (2014) 
HASIL DAN PEMBAHASAN

Hasil Penelitian

1. Karakteristik responden penelitian

a. Umur

Tabel 1. Distribusi frekuensi karakteristik usia responden

\begin{tabular}{llll}
\hline No. & $\begin{array}{l}\text { Usia } \\
\text { (Tahun) }\end{array}$ & Frekuensi & $\begin{array}{l}\text { Prosentas } \\
\text { e (\%) }\end{array}$ \\
\hline 1. & $20-30$ & 23 & 65,7 \\
2. & $>30$ & 12 & 34,3 \\
\hline & Jumlah & 35 & 100
\end{tabular}

Berdasarkan tabel 1 dapat dilihat bahwa dari 35 responden mayoritas berusia 20-30 tahun yaitu 23 orang $(65,7 \%)$.

b. Pendidikan Terakhir

$\begin{array}{llr}\begin{array}{l}\text { Tabel 2. } \\ \text { karakteristik }\end{array} & \begin{array}{l}\text { Distribusi } \\ \text { pendidikan }\end{array} & \begin{array}{r}\text { frekuensi } \\ \text { terakhir }\end{array} \\ \text { responden } & & \end{array}$
responden

\begin{tabular}{llll}
\hline No. & $\begin{array}{l}\text { Pendidikan } \\
\text { Terakhir }\end{array}$ & $\begin{array}{l}\text { Frekuens } \\
\mathbf{i}\end{array}$ & $\begin{array}{l}\text { Prosentas } \\
\mathbf{e} \\
\mathbf{( \% )}\end{array}$ \\
\hline 1. & $\begin{array}{l}\text { Tinggi } \\
\text { (Perguruan } \\
\text { Tinggi) } \\
\text { Menengah } \\
\text { (SMA) } \\
\text { Dasar (SD, }\end{array}$ & 212 & 5,7 \\
SMP) & 60,0 \\
\hline & Jumlah & 34,3 \\
\hline
\end{tabular}

Berdasarkan tabel 2 dapat dilihat bahwa mayoritas pendidikan terakhir dari 35 responden yaitu sekolah menengah (SMA) sebanyak 21 orang $(60,0 \%)$

c. Informasi

Tabel 3. Distribusi frekuensi karakteristik media informasi responden

\begin{tabular}{llll}
\hline No. & $\begin{array}{l}\text { Media } \\
\text { Informasi }\end{array}$ & Frekuensi & $\begin{array}{l}\text { Prosentas } \\
\text { e(\%) }\end{array}$ \\
\hline 1. & Media & 15 & 42,9 \\
& Massa & & \\
2. & Teman & 6 & 17,1 \\
3. & Tidak & 14 & 40,0 \\
& Pernah & & \\
& Mendengar & & 100
\end{tabular}

Berdasarkan tabel 3 dapat dilihat bahwa mayoritas dari 35 responden yang mendapatkan informasi melalui media massa sebanyak 15 responden $(42,9 \%)$.
2. Tingkat Pengetahuan Ibu tentang Perkembangan Motorik Kasar Balita Umur 3-4 Tahun di Playgroup Cepaka 2 Semanggi Surakarta

a. Pengetahuan tentang perkembangan motorik kasar

Tabel 4. Distribusi Frekuensi Pengetahuan tentang Perkembangan Motorik Kasar

\begin{tabular}{llll}
\hline No. & $\begin{array}{l}\text { Tingkat } \\
\text { Pengetahua } \\
\text { n }\end{array}$ & Frekuensi & $\begin{array}{l}\text { Prosen } \\
\text { tase } \\
(\%)\end{array}$ \\
\hline 1. & Baik & 2 & 5,7 \\
2. & Cukup & 19 & 54,3 \\
3. & Kurang & 14 & 40,0 \\
\hline & Jumlah & 35 & 100
\end{tabular}

Berdasarkan tabel 4 dapat dilihat bahwa dari 35 responden mayoritas tingkat pengetahuan yang cukup yaitu 19 responden $(54,3 \%)$.

b. Pengetahuan tentang pengertian

Tabel 5. Distribusi Frekuensi Tingkat Pengetahuan tentang Pengertian Perkembangan Motorik Kasar

\begin{tabular}{llll}
\hline No. & $\begin{array}{l}\text { Tingkat } \\
\text { Pengetahua } \\
\text { n }\end{array}$ & Frekuensi & $\begin{array}{l}\text { Prosentas } \\
\text { e(\%) }\end{array}$ \\
\hline 1. & Baik & 7 & 20,0 \\
2. & Cukup & 15 & 42,9 \\
3. & Kurang & 13 & 37,1 \\
\hline & Jumlah & 35 & 100
\end{tabular}

Berdasarkan data tersebut dapat dilihat bahwa dari 35 responden secara keseluruhan memiliki tingkat pengetahuan yang cukup yaitu 15 responden $(42,9 \%)$

c. Pengetahuan tentang macam

Tabel 6. Distribusi Frekuensi Tingkat Pengetahuan tentang Macam Perkembangan Motorik Kasar

\begin{tabular}{llll}
\hline No. & $\begin{array}{l}\text { Tingkat } \\
\text { Pengetahua } \\
\text { n }\end{array}$ & Frekuensi & $\begin{array}{l}\text { Prosentas } \\
\text { e(\%) }\end{array}$ \\
\hline 1. & Baik & 4 & 11,4 \\
2. & Cukup & 13 & 37,1 \\
3. & Kurang & 18 & 51,4 \\
\hline & Jumlah & 35 & 100
\end{tabular}

Berdasarkan tabel 6 dapat dilihat bahwa dari 35 responden mayoritas tingkat pengetahuan yang kurang yaitu 18 responden $(51,4 \%)$ 
Tabel 7. Distribusi Frekuensi Tingkat Pengetahuan tentang Unsur Perkembangan Motorik Kasar

\begin{tabular}{llll}
\hline No. & $\begin{array}{l}\text { Tingkat } \\
\text { Pengetahuan }\end{array}$ & Frekuensi & $\begin{array}{l}\text { Prosen } \\
\text { tase } \\
(\%)\end{array}$ \\
\hline 1. & Cukup & 17 & 48,5 \\
2. & Kurang & 18 & 51,4 \\
\hline & Jumlah & 35 & 100
\end{tabular}

Berdasarkan tabel 7 dapat dilihat bahwa dari 35 responden mayoritas tingkat pengetahuan yang kurang yaitu 18 responden $(51,4 \%)$

e. Pengetahuan tentang Faktor

Tabel 8. Distribusi Frekuensi Tingkat Pengetahuan Ibu tentang Faktor Perkembangan Motorik Kasar

\begin{tabular}{llll}
\hline No. & $\begin{array}{l}\text { Tingkat } \\
\text { Pengetahuan }\end{array}$ & Frekuensi & $\begin{array}{l}\text { Prosentas } \\
\text { e (\%) }\end{array}$ \\
\hline 1. & Baik & 17 & 48,6 \\
2. & Cukup & 8 & 22,9 \\
3. & Kurang & 10 & 28,6 \\
\hline & Jumlah & 35 & 100
\end{tabular}

Berdasarkan tabel 8 dapat dilihat bahwa dari 35 responden mayoritas tingkat pengetahuan yang baik yaitu 17 responden $(48,6 \%)$

f. Pengetahuan tentang Masalah

Tabel 9. Distribusi Frekuensi Tingkat Pengetahuan Ibu tentang Masalah Perkembangan Motorik Kasar

\begin{tabular}{llll}
\hline No. & $\begin{array}{l}\text { Tingkat } \\
\text { Pengetahua } \\
\text { n }\end{array}$ & Frekuensi & $\begin{array}{l}\text { Prosentas } \\
\text { e(\%) }\end{array}$ \\
\hline 1. & Baik & 4 & 11,4 \\
2. & Cukup & 17 & 48,6 \\
3. & Kurang & 14 & 40,0 \\
\hline & Jumlah & 35 & 100
\end{tabular}

Berdasarkan tabel 9 dapat dilihat bahwa dari 35 responden mayoritas tingkat pengetahuan yang cukup yaitu 17 responden $(48,6 \%)$

\section{Bahasan}

1. Tingkat Pengetahuan Ibu tentang Perkembangan Motorik Kasar

Hasil penelitian berdasarkan tabel distribusi menunjukkan bahwa tingkat pengetahuan ibu tentang perkembangan motorik kasar balita umur 3-4 tahun di Playgroup Cepaka 2 Semanggi Surakarta yaitu responden yang berpengetahuan baik sebanyak 2 orang $(5,7 \%)$, berpengetahuan cukup sebanyak 19 orang $(54,3 \%)$ dan berpengetahuan kurang sebanyak 14 orang $(40,0 \%)$. Berdasarkan data tersebut disimpulkan bahwa mayoritas responden mempunyai tingkat pengetahuan yang cukup tentang perkembangan motorik kasar balita umur 3-4 tahun.
Pengetahuan adalah hasil 'tahu', dan ini terjadi setelah orang melakukan pengindraan terhadap suatu obyek tertentu. Pengindraan terjadi melalui panca indra manusia, yakni indra penglihatan, pendengaran, penciuman rasa, dan raba. Sebagian besar pengetahuan manusia diperoleh melalui mata dan telinga (Notoatmodjo, 2011).

Faktor yang mempengaruhi tingkat pengetahuan ibu yaitu umur. Umur merupakan rentang waktu seseorang yang dimulai sejak dia dilahirkan hingga berulang tahun. Umur akan berpengaruh terhadap daya tangkap sehingga pengetahuan diperolehnya akan semakin baik (Ariani, 2014).

Hasil penelitian ini dikuatkan oleh penelitian terdahulu yang dilakukan oleh Masyroh (2013) dengan judul Gambaran Pengetahuan Ibu Yang Mempunyai Balita Tentang Obesitas Pada Lingkungan XIX di Kelurahan Banjai Kecamatan Medan Denai. Karakteristik dalam penelitian ini adalah umur dengan hasil ibu umur 20 tahun berpengetahuan baik sebanyak 11 responden $(31,4 \%)$, ibu umur 25 - 35 tahun berpengetahuan cukup sebanyak 19 responden $(54,3 \%)$ dan ibu umur $>35$ tahun berpengetahuan kurang sebanyak 5 responden $(14,3 \%)$. Hasil penelitian tersebut mayoritas pengetahuan responden cukup dipengaruhi oleh daya tangkap ibu dan menunjukkan bahwa terdapat hubungan antara umur dengan pengetahuan ibu.

Usia ibu di Playgroup Cepaka 2 Semanggi Surakarta mayoritas usia 20-30 tahun. Pada usia ini ibu mempunyai tingkat pengetahuan lebih baik dibandingkan dengan ibu yang berumur $>30$ tahun. Umur akan berpengaruh terhadap daya tangkap sehingga pengetahuan diperolehnya akan semakin baik.

2. Tingkat Pengetahuan Ibu tentang Pengertian Perkembangan Motorik Kasar

Hasil penelitian brdasarkan tabel distribusi menunjukkan bahwa tingkat pengetahuan ibu tentang pengertian perkembangan motorik kasar balita umur 3-4 tahun di Playgroup Cepaka 2 Semanggi, Surakarta yaitu mayoritas responden yang berpengetahuan cukup sebanyak 15 orang (42,9\%). Perkembangan motorik kasar adalah gerakan fisik yang membutuhkan keseimbangan dan koordinasi antar anggota tubuh, dengan menggunakan otot-otot besar, sebagian atau seluruh anggota tubuh (Soejiningsih, 2012).

Faktor yang mempengaruhi tingkat pengetahuan ibu yaitu pendidikan. Semakin tinggi pendidikan seseorang maka semakin mudah orang tersebut menerima informasi. Pengetahuan erat hubungannya dengan pendidikan, seseorang dengan pendidikan tinggi maka semakin luas pula pengetahuan yang dimiliki (Ariani, 2014). 
Hasil penelitian ini dikuatkan oleh penelitian terdahulu yang dilakukan oleh Puspitasari (2013) dengan judul Tingkat Pengetahuan Ibu Tentang Tumbuh Kembang Motorik Balita Usia 1-3 Tahun di Kelompok Bermain Sekar Melati Tasik Madu Karang Anyar didapatkan responden dengan pendidikan SD sebanyak 2 responden $(6,46 \%)$, SMP sebanyak 7 responden $(22,58 \%)$, SMA sebanyak $18(58,06 \%)$ dan Perguruan Tinggi sebanyak 4 responden $(12,90 \%)$.

Pengetahuan responden dipengaruhi oleh pendidikan. Dimana semakin tinggi pendidikan seseorang maka semakin mudah untuk menerima informasi. Pendidikan mayoritas ibu di Playgroup Cepaka 2 Semanggi Surakarta adalah sekolah menengah sehingga cukup pengetahuannya tentang perkembangan motorik balita.

3. Tingkat Pengetahuan Ibu tentang Macam Perkembangan Motorik Kasar

Hasil penelitian berdasarkan tabel distribusi menunjukkan bahwa tingkat pengetahuan ibu tentang macam-macam perkembangan motorik kasar balita umur 3-4 tahun di Playgroup Cepaka 2 Semanggi Surakarta yaitu mayoritas responden yang berpengetahuan kurang yaitu sebanyak orang $(51,4 \%)$. Menurut Mahendra (2006) macammacam perkembangan motorik kasar balita adalah keterampilan lokomotor, keterampilan nonlokomotor, dan keterampilan manipulatif.

Faktor yang mempengaruhi tingkat pengetahuan ibu yaitu informasi. Informasi adalah sesuatu yang diperoleh baik dari pendidikan formal maupun non formal dapat memberikan pengaruh jangka pendek (immediate impact) sehingga menghasilkan perubahan atau peningkatan pengetahuan (Notoatmojo, 2011).

Hasil penelitian ini dikuatkan oleh penelitian terdahulu yang dilakukan oleh Wulandari (2010) dengan judul Hubungan Status Gizi Dengan Perkembangan Motorik Kasar dan Motorik Halus Anak Usia 3-5 Tahun di Play Group Tranju Mas Purworejo didapatkan informasi yang didapatkan melalui teman $(32,0 \%)$, lingkungan sosial $(13,2 \%)$, media massa $(54,8)$. Hal ini dikarenakan perkembangan teknologi yang semakin canggih, sehingga semakin mudah untuk mencari informasi tentang perkembangan motorik kasar dari media massa.

Sumber informasi ibu di Playgroup Cepaka 2 Semanggi Surakarta mayoritas dari media massa, namun masih kurang dari 50\% yang berarti belum merata. Sesuai dengan hasil yang diperoleh dari penelitian yaitu sebagian besar ibu mempunyai tingkat pengetahuan kurang, maka dibutuhkan untuk penyuluhan tentang perkembangan motorik kasar balita di Playgroup Cepaka 2 Semanggi Surakarta.

4. Tingkat Pengetahuan Ibu tentang Unsur-Unsur Perkembangan Motorik Kasar

Hasil penelitian berdasarkan tabel distribusi menunjukkan bahwa tingkat pengetahuan ibu tentang unsur - unsur perkembangan motorik kasar balita umur 3-4 tahun di Playgroup Cepaka 2 Semanggi Surakarta yaitu mayoritas responden berpengetahuan kurang sebanyak 18 orang $(51,4 \%)$. Menurut Barrow Harold M., dan Mc Gee, Rosemary dalam Khoiriyah (2013) unsur unsur perkembangan motorik kasar yaitu: kekuatan, koordinasi, kecepatan, keseimbangan dan kelincahan.

Hasil penelitian ini dikuatkan oleh penelitian terdahulu yang dilakukan oleh Safitri (2012) dengan judul Gambaran Perkembangan Motorik Kasar Pada Anak Usia 3-5 Tahun di Desa Matang Karieng Kecamatan Seunuddon Kabupaten Aceh Utara didapatkan 17 responden (37\%) kategori baik dan 29 responden (63\%) kategori kurang, jadi pengetahuan responden tentang unsur-unsur perkembangan motorik mayoritas dalam kategori kurang. Hal ini dikarenakan responden belum mendapatkan informasi tentang perkembangan motorik Di Desa Matang Karieng Kecamatan Seunuddon Kabupaten Aceh Utara.

Unsur - unsur yang berpengaruh terhadap perkembangan motorik balita salah satunya yaitu dari ibu. Ibu yang mempunyai pengetahuan baik akan lebih aktif dalam mencari informasi tentang unsur-unsur perkembangan motorik untuk mengembangkan kemampuan motorik anaknya. Sehingga dapat disimpulkan bahwa semakin baik tingkat pengetahuan ibu berhubungan erat dengan semakin baik stimulasi yang diberikan ibu pada anaknya.

5. Tingkat Pengetahuan Ibu tentang Faktor Perkembangan Motorik Kasar

Hasil penelitian berdasarkan tabel distribusi menunjukkan bahwa tingkat pengetahuan ibu tentang faktor perkembangan motorik kasar balita umur 3-4 tahun di Playgroup Cepaka 2 Semanggi Surakarta yaitu mayoritas responden berpengetahuan baik sebanyak 17 orang $(48,6 \%)$ Menurut Soetjiningsih (2012), faktor - faktor yang mempengaruhi antara lain: motivasi belajar anak, pengetahuan ibu, lingkungan dan pendapatan.

Hasil penelitian ini dikuatkan oleh penelitian terdahulu yang dilakukan oleh Khoiriyah (2013) dengan judul Gambaran Pengetahuan Ibu Tentang Perkembangan Motorik Kasar Balita di Wilayah Puskesmas 
Mojolaban Sukoharjo didapatkan 21 responden $(67,7 \%)$ berpengetahuan baik, 8 responden $(25,8 \%)$ berpengetahuan cukup 2 sebagai $(6,4 \%)$ berpengetahuan kutrang. Hasil penelitian tersebut mayoritas responden berpengetahuan baik.

Faktor - faktor yang berpengaruh terhadap perkembangan motorik balita salah satunya yaitu pengetahuan ibu. Ibu yang mempunyai pengetahuan baik akan memberikan stimulasi pada balita sesuai dengan umurnya.

6. Tingkat Pengetahuan Ibu tentang Masalah Perkembangan Motorik Kasar

Hasil penelitian berdasarkan tabel distribusi menunjukkan bahwa tingkat pengetahuan ibu tentang masalah perkembangan motorik kasar balita umur 3-4 tahun di Playgroup Cepaka 2 Semanggi Surakarta yaitu mayoritas responden berpengetahuan cukup sebanyak 17 orang $(48,6 \%)$. Masalah perkembangan motorik kasar balita adalah ketidakmampuan mengatur keseimbangan dan reaksi kurang cepat serta koordinasi kurang baik (Wiyani, 2014).

Hasil penelitian ini dikuatkan oleh penelitian terdahulu yang dilakukan oleh Kusuma (2012) dengan judul Hubungan Tingkat Pengetahuan Ibu Tentang Tumbuh Kembang dan Perkembangan Motorik Balita di Wilayah Kerja Puskesmas Penumping Surakarta, dimana hasil penelitian menunjukkan responden yang berpengetahuan baik $(15,7 \%)$, responden yang berpengetahuan cukup $(54,3 \%)$ dan responden yang berpengetahuan kurang $(30,0 \%)$. Penelitian ini mayoritas responden berpengetahuan cukup.

Sesuai dengan hasil yang diperoleh dari penelitian yaitu sebagian besar ibu mempunyai tingkat pengetahuan cukup. Masalah perkembangan motorik kasar adalah tanda adanya keterlambatan perkembangan motorik kasar sehingga perlu mengetahui masalah yang muncul pada balita sehingga dapat mendeteksi secara dini.

\section{KESIMPULAN}

\section{Simpulan}

Tingkat pengetahuan ibu tentang perkembangan motorik kasar pada balita umur 3-4 tahun di Playgroup Cepaka 2 Semanggi Surakarta mayoritas dalam kategori cukup

\section{Saran}

Bagi ibu diharapkan meningkatkan kesadaran pentingnya untuk menambah pengetahuan tentang perkembangan motorik kasar pada balita. Bagi tenaga kesehatan diharapkan meningkatkan peran sebagai fasilitator penyedia informasi kesehatan khususnya perkembangan anak.

\section{DAFTAR PUSTAKA}

Adriana, D. 2013. Tumbuh Kembang dan Terapi Bermain Pada Anak. Jakarta: Salemba Medika. h. 13

Ariani, A.P. 2014. Aplikasi Metodologi Penelitian Kebidanan dan Kesehatan Reproduksi. Yogyakarta: Nuha Medika. h. 23-26, 27, 57, 74, 75-76, 77

Budiarto. Biostatistik Untuk Kedokteran \& Kesehatan Masyarakat. Jakarta : EGC ; 2011.h. 143

Dewi. 2013. Asuhan Neonatus Bayi \& Anak Balita. Jakarta : Salemba Medika ;.h. 66, 67

Khoiriyah, S. 2013. Gambaran Pengetahuan Ibu tentang Perkembangan Motorik Kasar Balita di Wilayah Puskesmas Mojolaban Sukoharjo. Didapat dari eprints.ums.ac.id/23908.pdf

Kusuma, R. 2012. Hubungan Tingkat Pengetahuan Ibu Tentang Tumbuh Kembang dan Perkembangan Motorik Balita di Wilayah Kerja Puskesmas Penumping Surakarta. Didapat eprints.ums.ac.id/5008009/1.pdf

Mahendra, A. 2006. Perkembangan Dan Belajar Motorik. Didapat dari Modul file.upi.edu/direktori/FPOK/JUR._PEND. OLAHRAGA/196308241989031AGUS_MAHENDRA/MODUL_UT_2006_ AGUS_MAHENDRA/MODUL_1.pdf

Masyroh. 2013. Gambaran Pengetahuan Ibu Yang Mempunyai Balita Tentang Obesitas Pada Lingkungan XIX di Kelurahan Banjai Kecamatan Medan Denai. Didapat dari MASYROH_2013-2837-6214.pdf

Notoatmodjo, S. 2010. Metodologi Penelitian Kesehatan. Jakarta: Rineka Cipta. h. 11-18, 27, 35, 87, 103, 112, 130, 171, 182.

2011. Kesehatan Masyarakat Ilmu dan Seni. Jakarta: Rineka Cipta. h. 147-149

Nursalam. 2008. Metodologi Penelitian Ilmu Keperawatan. Jakarta : Salemba Medika ;.h.33-34

Puspitasari, HD. 2013 Tingkat Pengetahuan Ibu Tentang Tumbuh Kembang Motorik Balita Usia 1-3 Tahun di Kelompok Bermain Sekar Melati Tasik Madu Karang Anyar. Didapat dari: 01-gdl-henidwipus-386-1-hennidw4.pdf 
Safitri, M. 2012. Gambaran Perkembangan Motorik Kasar Pada Anak Usia 3-5 Tahun Di Desa Matang Karieng Kecamatan Seunuddon Kabupaten Aceh Utara. Didapat dari Marlina_Safitri-09010224.pdf

Soejiningsih. 2012. Tumbuh Kembang Anak Edisi 2. Jakarta: Buku Kedokteran EGC. h. 108

Sugiyono. 2010. Metode Penelitian Kuantitatif, Kualitatif, $R$ dan D. Bandung: Alfabeta. h. 81,85

Sulistyawati, A. 2014. Deteksi Tumbuh Kembang Anak. Jakarta: Salemba Medika. h. 60
Wiyani, N. 2014. Psikologi Perkembangan Anak Usia Dini. Yogyakarta: GAVA MEDIA. h.13

Wulandari, M. 2010. Hubungan Status Gizi Dengan Perkembangan Motorik Kasar dan Motorik Halus Anak Usia 3-5 Tahun di Play Group Tranju Mas Purworejo. Didapat dari 1544321080201002291.pdf 